\title{
Protein content and protein synthesis rates of planktonic marine bacteria
}

\author{
Meinhard Simon*, Farooq Azam \\ Institute of Marine Resources A-018, Scripps Institution of Oceanography, UCSD, La Jolla, California 92093-0218, USA
}

\begin{abstract}
Bacterial carbon production is an important parameter in understanding the flows of carbon and energy in aquatic ecosystems, but has been difficult to measure. Present methods are based on measuring the rate of cell production, and thus require a knowledge of cellular carbon content of the growing bacteria to convert cell production into carbon production. We have examined the possibility that protein synthesis rate of pelagic bacteria might serve as the basis for directly estimating bacterial carbon production. We measured bacterial protein content and protein production of pelagic bacteria. Bacterial protein content was measured as amino acids by high performance liquid chromatography of cell hydrolysates of bacterial assemblages of mean diameters from 0.026 to $0.4 \mu \mathrm{m}$. Cellular protein:volume $(\mathrm{w} / \mathrm{v})$ in the largest bacteria was $15.2 \%$ (similar to cultured Escherichia coll) but increased with decreasing cell size to $46.5 \%$ in $0.026 \mu \mathrm{m}$ bacteria. Protein per bacterium was correlated with cell volume by the power function $y=88.6 x^{0.59}\left(r^{2}=0.67 ; p<0.01 ; n=25\right)$. An inventory of major bacterial macromolecular pools revealed that cell protein:dry weight and cell protein:carbon were essentially constant $(63 \%$ and $54 \%$, respectively) for the entire cell size range although cell protein:volume increased with decreasing cell size. Thus, the smaller cells in the size range were rich in carbon and dry weight and poor in water compared with larger cells. We established the experimental conditions for estimating protein synthesis on the basis of ${ }^{3} \mathrm{H}$ leucine incorporation by bacteria, and determined the necessary parameters (including the intracellular isotope dilution by HPLC) for converting ${ }^{3} \mathrm{H}$ leucine incorporation into protein synthesis rate. In samples from Scripps Institution of Oceanography pier the intracellular isotope dilution was only 2 -fold. In a field study in Southern California Bight bacterial protein production and ${ }^{3} \mathrm{H}$-thymidine incorporation methods yielded comparable rates of bacterial production. Bacterial protein production method was an order of magnitude more sensitive and yielded bacterial carbon production directly without the need to know the cell size of the part of the assemblage in growth state.
\end{abstract}

\section{INTRODUCTION}

Bacterial biomass and production measurements over the past 10 yr have shown that heterotrophic bacteria represent a major pathway for the flux of organic matter in marine and limnic pelagic ecosystems (review by Cole et al. 1988). This realization has fundamentally altered our conception of the structure of aquatic food webs by suggesting that a dissolved organic matter $\rightarrow$ bacteria $\rightarrow$ protozoa $\rightarrow$ metazoa loop processes roughly as much energy as the classical grazing food chain (Azam et al. 1983, Riemann \& Søndergaard 1986). Further, there is recent evidence of a major role of bacteria as a biomass component in oligoto mesotrophic aquatic environments (Simon \& Tilzer

\footnotetext{
- Addressee for correspondence; present address: Limnological Institute, University of Constance, PO Box 5560, D-7750 Konstanz, Federal Republic of Germany
}

1987. Cho \& Azam 1988) and in the depth-dissipation of sinking organic matte: in the ocean's interior (Cho \& Azam 1988). There is considerable interest, therefore, in quantifying the flow of organic matter and energy through bacteria in pelagic ecosystems. Such studies require measurements of the biomass content of bacteria, their growth efficiency, and the rates of bacterial biomass production.

Methods for quantifying bacterial biomass and rates of bacterial production have been evolving. An important recent finding is that natural assemblages of bacteria are very rich in carbon and nitrogen; they contain 23 to $38 \%(\mathrm{w} / \mathrm{v})$ carbon, compared with $12 \%$ for cultured Escherichia coli (Ingraham et al. 1983, Bjørnsen 1986, Lee \& Fuhrman 1987). Apparently, the bacterial $\mathrm{C}$ /biovolume ratio increases as the cell size decreases. Such high C/biovolume values, if correct, would have major implications for planktonic carbon budgets and estimates of carbon flow through the mi- 
crobial loop. One goal of our study was to constrain, by an independent method, the $\mathrm{C} /$ biovolume relationship which had previously been determined by CHN analysis. Our approach was to obtain an approximate macromolecular inventory of natural assemblages of bacteria (obtained by size fractionation or grown in seawater culture) and use it as a basis of minimum estimates of bacterial biomass carbon. Carbon comprises about $50 \%$ and protein 50 to $70 \%$ of the dry weight of cultured bacteria (Herbert 1976). So measurements of protein alone might suffice for testing if the high cellular carbon amounts appear reasonable.

Bacterial carbon production in natural samples is often measured on the basis of DNA synthesis by the tritiated thymidine incorporation method (TdR, Fuhrman \& Azam 1980, 1982, Moriarty 1986). A difficulty is that this method measures cell multiplication, which must then be translated into bacterial carbon production from a knowledge of the carbon content of the growing bacteria in natural assemblages. It would be highly desirable to develop a method to directly measure bacterial carbon production without the need of knowing the per-cell carbon content. One approach would be to measure bacterial production in terms of a cellular component which makes up a large fraction of bacterial biomass and has a reasonably predictable relationship with cell carbon and dry weight. If indeed protein comprised a large biomass fraction of the diminutive planktonic bacteria the protein syrithesis rate could be a suitable basis for measuring biomass (and thus carbon) production.

Two radiotracer approaches have been proposed in the past to measure bacterial protein production (BPP) in seawater samples. Cuhel et al. (1982) proposed ${ }^{35} \mathrm{~S}$ sulfate incorporation into protein as the basis of calculating BPP. This approach has found only limited use in marine studies because sulfate incorporation into plankton is not bacteria-specific and because the high sulfate concentration in seawater leads to excessive isotope dilution of ${ }^{35} \mathrm{~S}$-sulfate. Kirchman et al. (1985) proposed that BPP could be calculated on the basis of the rates of ${ }^{3} \mathrm{H}$-leucine incorporation into bacterial protein. Leucine, added at $n M$ concentrations, is taken up virtually exclusively by bacteria in marine plankton (Kirchman et al. 1985). To convert leucine incorporation rates into BPP, Kirchman et al. $(1985,1986)$ and Chin-Leo \& Kirchman (1988) used a relationship between both parameters derived from the literature on cultured bacteria, or empirically by concurrently monitoring the increase in bacterial abundance. We have extended the work of Kirchman et al and sought to establish a relationship between leucine incorporation and protein synthesis by directly measuring the necessary parameters in natural bacterial assemblages or in seawater cultures. These parameters include: (1)
${ }^{3} \mathrm{H}$-leucine isotope dilution due to de novo synthesis of leucine, (2) per-cell protein content of natural planktonic bacteria, (3) the protein:cell volume relationship and its dependence on the cell size, and (4) mol\% leucine in protein of natural bacterial assemblages. Finally, we compared the BPP and TdR methods in depth profiles in the Southern California Bight, USA, to test the BPP method in the field.

\section{MATERIALS AND METHODS}

Experimental system. Three types of experimental systems were used for determining bacterial protein, leucine incorporation, and the parameters for determining the BPP conversion factors. (1) The bacterial fraction $(<0.6 \mu \mathrm{m})$ of seawater samples. We were aware that while this system should not contain significant amounts of non-bacterial organisms it might contain some nano-detritus which could increase bacterial protein estimates. (2) Seawater cultures (Ammerman et al. 1984). This system has 2 advantages: (a) bacteria in seawater cultures are virtually free of detritus; (b) bacteria in seawater cultures go through changes in growth dynamics and size-frequency distribution which cover the range of these variables typical of natural pelagic assemblages. It is, therefore, a good system for studying how the measured parameters may vary with bacterial growth rate and cell size. (3) Natural 'raw' seawater samples were used for measuring environmental rates of BPP- and TdR-based bacterial production.

Sampling sites. Samples were collected at the end of the pier of Scripps Institution of Oceanography $\left(32^{\circ} 53^{\prime} \mathrm{N}, 117^{\circ} 15^{\prime} \mathrm{W}\right)$ in acid-washed and autoclaved polycarbonate bottles. Samples were processed within $30 \mathrm{~min}$. First, the samples were pre-filtered gently $(0.15$ bar) through $0.6 \mu \mathrm{m}$ Nuclepore filters. Most bacteria passed this filter while the passage of other organisms was negligible. Profiles for BPP and TdR measurements were taken during a cruise in the Southern California Bight (coordinates given in Fig. 5 legend).

Growth experiments with $0.6 \mu \mathrm{m}$ filtrates or seawater cultures. Our purpose was to monitor growing bacterial assemblages with respect to bacterial abundance, cell volume, cellular protein content, cellular amino acid pools, and leucine incorporation. We expected that growing cultures will exhibit dynamics of these parameters thus allowing us to look for relationships between various parameters.

We did 3 growth experiments, one with a seawater culture (11 June 1986 [Exp.1]), and two with the undiluted bacterial fraction i.e. $0.6 \mu \mathrm{m}$ filtrates (27 October 1986 [Exp. 2] and 10 January 1987 [Exp. 3]). For Exps. 2 and 3 seawater filtered through $0.6 \mathrm{um}$ Nuclepore fil- 
ters was transferred to acid-washed glass bottles and incubated in the dark at $19^{\circ} \mathrm{C}$ (which was within $4 \mathrm{C}^{\circ}$ of ambient seawater temperature). Subsamples were withdrawn periodically for various above-mentioned parameters using $500^{\circ} \mathrm{C}$ combusted glass pipets to minimize the possibility of contamination with amino acids or proteins.

Enumeration and volume determination of bacteria. Bacteria were enumerated by the acridine orange direct count (AODC) method (Hobbie et al. 1977). Bacteria were sized from enlarged photomicrographs $(\times 4300)$ using a digitizer (Hewlett Packard 9874 A) according to Simon (1987). Usually 40 to 120 cells were sized on each filter. To compute the cell volume we considered the rod-shaped cells to be cylinders with a hemispherical cap, and cocci to be spheres. No correction was made for possible cell shrinkage as a result of sample preparation.

Bacterial growth rate. The bacterial growth rate was calculated by the equation for exponential growth:

$$
\mu=\left(\ln N_{2}-\ln N_{1}\right) /\left(t_{1}-t_{2}\right)
$$

where $N_{1}$ and $N_{2}=$ bacterial abundance at the beginning and the end of an incubation interval; $t_{1}$ and $t_{2}=$ the corresponding times.

Leucine and thymidine incorporation. $\left.\left[3,4,5-{ }^{3} \mathrm{H}\right]-\right]-$ leucine $(140 \mathrm{Ci} \mathrm{mmol}-1$, New England Nuclear) was added to triplicate $10 \mathrm{ml}$ samples to $0.5 \mathrm{nM}$ (Exp. 1) or $10 \mathrm{n} M$ (Exp. 3 and field data) final concentrations. Formalin-treated controls were run in parallel. We expected the $10 \mathrm{n} M$ additions to (a) overwhelm the ambient leucine pool (about $1 \mathrm{nM}$ ) so that the final specific activity of extracellular leucine would approximate the specific activity of the added leucine, and (b) maximize leucine uptake and hence its participation in protein synthesis. Incubations were at room temperature and were terminated by adding buffered formalin $(0.4 \%$ final concentration, $\mathrm{pH} 8)$. To determine ${ }^{3} \mathrm{H}$ leucine incorporation into protein the samples were extracted with $5 \%$ trichloracetic acid (TCA) at 95 to $100^{\circ} \mathrm{C}$ for $30 \mathrm{~min}$. We systematically optimized the extraction conditions (temperature, time, and TCA concentration) to achieve complete hydrolysis of DNA and RNA with minimal hydrolysis of protein. The conditions we chose resulted in $<13 \%$ of protein hydrolysis as checked by HPLC analysis of free amino acids. Longer extraction periods lead to significant protein hydrolysis (data not shown). The extracted samples were cooled, filtered onto $0.45 \mu \mathrm{m}$ cellulose membrane filters (Millipore or Sartorius) and rinsed with $5 \mathrm{ml}$ filtered seawater. One ml ethylacetate was added to dissolve the filter and thus to increase ${ }^{3} \mathrm{H}$ counting efficiency. The samples were then radioassayed in a Beckman LS 100$C$ liquid scintillation spectrometer using Betaphase or Ecolite (WestChem, San Diego, California) as the fluor.
Quenching was corrected by the external standard ratio method.

In Exp. 3 we determined if ${ }^{3} \mathrm{H}$ in the protein fraction was in fact incorporated as ${ }^{3} \mathrm{H}$-leucine; possibly, metabolism of ${ }^{3} \mathrm{H}$-leucine transferred some label to other amino acids which then became incorporated into protein. We tested this by hydrolysis of cell protein followed by HPLC analysis of amino acids. We used the same procedure as for bacterial particulate amino acid analysis (below) with the difference that individual amino acid 'peaks' were collected from the column effluent for radioassay. In practice, we used a fractioncollector which collected individual fractions.

TdR incorporation into the ice-cold TCA precipitate was measured by adding methyl- $\left[{ }^{3} \mathrm{H}\right]$-thymidine $(70 \mathrm{Ci}$ $\mathrm{mmol}^{-1}$, New England Nuclear) to the sample at a final concentration of $5 \mathrm{nM}$ according to Fuhrman \& Azam (1982). Formalin-treated controls were run in parallel. After stopping the incubation with buffered formalin ( $0.4 \%$ final concentration) samples were filtered onto $0.45 \mu \mathrm{m}$ cellulose membrane filters, extracted with icecold $5 \%$ TCA and radioassayed. TdR incorporation rates were converted to cell multiplication rates by the conversion F1 $\times 1.7 \times 10^{18}$ cells $(\mathrm{mol} \mathrm{TdR})^{-1}$ (Fuhrman \& Azam 1982). F1 denotes the ${ }^{3} \mathrm{H}$ amount in DNA as \% of the cold TCA precipitate. It was $80 \%$ in the euphotic zone decreasing with depth to $29 \%$ at $450 \mathrm{~m}$ and below. From below the euphotic zone to $450 \mathrm{~m}$ F1 was calculated by the regression equation $\mathrm{F} 1=60.924-0.0709 \times$ depth $(\mathrm{m}$; Cho \& Azam 1988). Cell multiplication rates were converted to carbon production by using our computed cell carbon values for the given cell size (see Table 5).

Bacterial particulate protein, dissolved protein, and amino acid analysis. Particulate protein measurement in sparse bacterial assemblage samples could be done sensitively by hydrolysis to amino acids followed by High Performance Liquid Chromatography (HPLC) analysis. Another advantage of this approach over measuring bulk protein or bulk protein hydrolysate was that we could simultaneously determine the mol\% of leucine and other amino acids in protein. Further, as explained above, we were able to check whether or not ${ }^{3} \mathrm{H}$ was incorporated into protein directly as ${ }^{3} \mathrm{H}$-leucine. As shown by the results it is justified to refer to bacterial particulate amino acids (BPAA) as 'bacterial protein'.

Dissolved combined amino acids (DCAA, dissolved protein) were measured mainly to standardize our protein measurements and to monitor protein utilization from seawater during incubations of Exps. 1 to 3. They were measured by acid hydrolysis to amino acids followed by HPLC analysis (see below).

To prepare the samples for bacterial protein analysis, bacteria in 50 to $250 \mathrm{ml}$ samples were concentrated on a $0.2 \mu \mathrm{m}, 47 \mathrm{~mm}$ diameter Nuclepore fiiter using gentle vacuum $(0.1 \mathrm{bar})$. They were resuspended in $10 \mathrm{ml}$ of 
an organic-free salt solution of $\mathrm{pH} 6.2(9 \mathrm{ml}$ water + $1 \mathrm{ml} 0.8 \mathrm{M}$ borate buffer $\mathrm{pH} 12.5+120 \mu \mathrm{l} 6 \mathrm{~N} \mathrm{HCl}$. Bacteria did not lyse for up to several days in this $13 \%$ salt solution. Resuspension efficiency was usually only 25 to $50 \%$, but this was not a problem because we could normalize bacterial protein in cell suspensions on per-cell or per-cell volume bases by counting and sizing bacteria. We found high glycine, serine, and alanine concentrations after resuspension, suggesting contamination by these amino acids (and not by protein) during sample preparation. We reduced our protein values to correct for the contamination.

The samples for bacterial protein and DCAA were hydrolyzed to the component amino acids by heating in $6 \mathrm{~N} \mathrm{HCl}$ at $110^{\circ} \mathrm{C}$ for $20 \mathrm{~h}$ in $\mathrm{N}_{2}$-purged ampules. Under these conditions, asparagine and glutamine are deaminated to aspartic and glutamic acids and tryptophane is destroyed (Herbert et al. 1971). We tested the accuracy of our protein analysis using a bovine serum albumin (BSA) standard. Our results were within $14 \%$ of the standard's concentration. We also calculated the mol\% of various amino acids and compared them with the literature value of the mol\% of BSA (Reeck 1983). Our results were within $30 \%$ of the published molar composition of BSA.

Dissolved free amino acids (DFAA, either originally present as such or produced by hydrolysis of bacterial protein or DCAA) were analyzed by HPLC on an Econosphere $25 \mathrm{~cm} \times 5 \mu \mathrm{m}$ analytical column (Alltech Assoc.) using a modification of the ortho-phthaldialdehyde (OPA) pre-column derivatization technique of Lindroth \& Mopper (1979). Prior to analysis samples were pre-filtered through a $0.2 \mu \mathrm{m}$ Gelman (Acrodisc R), Millipore, Sartorius (Minisart) or Nuclepore filter. There was no significant difference in DCAA concentrations after filtration through either of these filters. However, bacterial protein and DCAA samples of Exp. 1 were pre-filtered through a Gelman Acrodisc CR filter which significantly adsorbed non-polar amino acids, in particular leucine. For calculating amino acid mol\% of bacterial protein we excluded these samples (see 'Results'). The binary elution gradient of methanol and $50 \mathrm{mM}$ sodium acetate $\mathrm{pH} 5.9+2 \%(\mathrm{v} / \mathrm{v})$ tetrahydrofurane was a slight modification from Fuhrman \& Bell (1985). OPA derivatization and DFAA analysis was done as in Fuhrman \& Bell (1985). Since proline does not react with OPA it could not be analyzed. Further, cysteine and lysine were never detected within the first $19 \mathrm{~min}$ of elution. The elution sequence of the amino acids analyzed is listed in Table 3 . Threonine and glycine, and alanine and arginine always co-eluted and were not further resolved. Methionine often was not detected or coeluted with valine.

${ }^{3} \mathrm{H}$-leucine specific activity in the bacterial intracellular pool. Our objective was to determine both the time-course of increase of the intracellular ${ }^{3} \mathrm{H}$-leucine specific activity and the specific activity maximum reached during the incubation. Bacterial fractions of seawater were incubated with $7 \mathrm{n} M^{3} \mathrm{H}$-leucine $(18.8 \mathrm{Ci}$ $\left.\mathrm{mmol}^{-1}\right)$. Triplicate subsamples $(150 \mathrm{ml})$ were withdrawn periodically, filtered quickly onto $0.2 \mu \mathrm{m}, 47 \mathrm{~mm}$ Nuclepore filters and dipped rapidly into boiling double-distilled water to extract the intracellular pools for 3 to $4 \mathrm{~min}$. The reason for rapid manipulation was to minimize changes in pool specific activity due to de novo synthesis. The extracted samples were chilled and kept on ice until all samples had been collected and were then analyzed by HPLC. While our main purpose was to measure leucine and ${ }^{3} \mathrm{H}$ in the leucine peak, we also fractionated the remaining effluent into 1 min fractions and radioassayed them to see if ${ }^{3} \mathrm{H}$ entering the cells as leucine had been metabolized.

\section{RESULTS}

\section{Bacterial volume and protein content}

In all 3 incubations growth roughly paralleled total bacterial volume and protein (Fig. 1), although the growth patterns differed somewhat in different incubations. Growth rates varied with time; values calculated for each time interval for Exp. 3 are shown in Table 1. Exp. 1 showed a $6 \mathrm{~h}$ lag until bacteria started to multiply (a similar lag was reported by Ammerman et al 1984). Protein concentrations showed a strong correlation with biovolume (linear correlation, $\left[r^{2}\right]$ Exp. $1=$ 0.92 ; Exp. $2=0.89 ;$ Exp. $3=0.71$ ). Mean cell volume (Fig. 1) showed an initial decrease in all incubations. It. continued to decrease in Exp. 1 (which had a quite high initial cell volume) but increased somewhat in the other incubations. Bacterial protein per cell initially decreased in all cases (especially in Exp. 1 which showed a $50 \%$ decrease, roughly paralleling the decrease in cell volume). Fig. 2 shows that there is a significant correlation between bacterial protein per cell $(y)$ and the mean cell volume $(x)$ for the data in Fig. 1 plus additional data for $0.4 \mu \mathrm{m}$ filtrates from Scripps pier (the 4 lowest values):

$$
y=88.6 x^{0.59} \quad\left(r^{2}=0.67 ; p<0.01 ; n=25\right)
$$

As indicated in Table 5, protein has to be increased by $18 \%$ for calculating cell protein from cell volume by this equation.

\section{Amino acid mol\%}

Bacterial protein in our samples had an amino acid mol\% (mean of 47 samples) quite similar to the litera- 

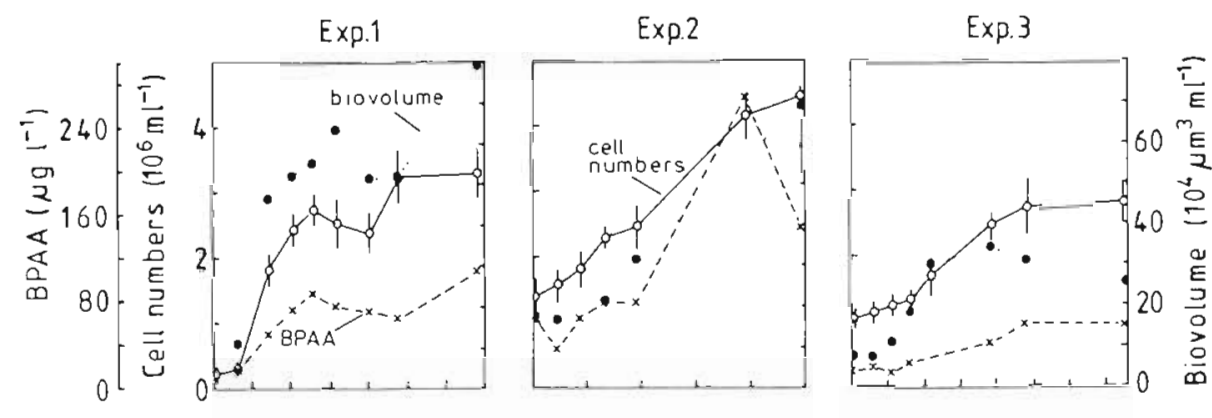

Fig. 1 Upper: Bacterial protein amino acids (BPAA: $\mathrm{x}-\cdots-\mathrm{x}$ ), cell numbers $(0-0$, with standard error $[S E]$ ), and biovolume $(\bullet \cdots \bullet)$. Lower: BPAA cell ${ }^{-1}(0-$ with SE of duplicates) and cell volume $(\bullet \cdot \bullet \bullet$. Exp. 1 was a seawater culture and Exps. 2 and 3 were time courses of $0.6 \mathrm{um}$ filtrates from Scripps pier. In Exp. 2 no sample for BPAA was taken at $22 \mathrm{~h}$
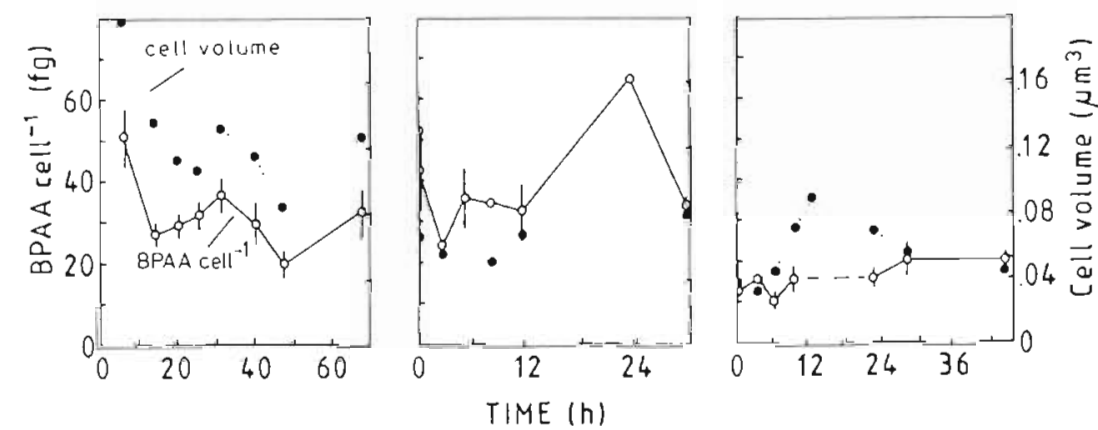

Table 1 . Growth rate $(\mu)$, leucine in protein per cell (Pleu), leucine incorporation into the hot TCA precipitate (leu inc $)$, and leucine produced in protein (leu $\mathrm{u}_{\text {prod }}$ ) during a time course of a $0.6 \mu \mathrm{m}$ pre-filtered sample from Scripps pier (Exp. 3). The incorporation rate comprises all exogenous leucine taken up as calculated from the specific activity of ${ }^{3} \mathrm{H}$-leucine added and the ambient concentration. Leuprod is calculated from Pleu and the growth rates for the various time intervals

\begin{tabular}{|c|c|c|c|c|c|}
\hline $\begin{array}{l}\text { Time } \\
\text { (h) }\end{array}$ & $\begin{array}{c}\mu \\
\left(h^{-1}\right)\end{array}$ & $\begin{array}{c}\text { Pleu } \\
\text { (nmol) }\end{array}$ & \multicolumn{2}{|c|}{$\left(\mathrm{pmol} \mathrm{l}^{-1} \mathrm{~h}^{-1}\right)$} & $\frac{l e u_{\text {inc }}}{l e u_{\text {prod }}} \times 100$ \\
\hline 0 & 0.033 & 6.5 & 74.9 & 214.8 & 34.9 \\
\hline 3 & 0.033 & 10.4 & 119.4 & 343.2 & 34.8 \\
\hline 6 & 0.033 & 6.5 & 86.7 & 215.5 & 40.4 \\
\hline 9 & 0.079 & 5.2 & 416.8 & 431.6 & 96.6 \\
\hline 22 & 0.020 & 14.7 & 138.0 & 294.0 & 46.9 \\
\hline 28 & 0.002 & 21.9 & 201.0 & 43.8 & 458.9 \\
\hline
\end{tabular}

ture values of purified bacterial proteins (mean of 69 proteins, Reeck 1983, Table 2 ). The mol\% of leucine and aspartic acid showed least variation in all experiments with coefficients of variation of 0.26 and 0.24 $(\mathrm{SD} / \mathrm{mean})$. In relation to our goal of using leucine as a measure of protein synthesis we note that leucine mol\% was $7.3 \pm 1.9$. As discussed in 'Materials and Methods' we have excluded Exp. 1 in calculating the amino acid mol\% because of selective adsorption of neutral amino acids on filters in this experiment.

\section{Isotope dilution}

Since the ambient leucine concentration was generally $<1 \mathrm{n} M$ extracellular isotope dilution would be negligible in experiments where $10 \mathrm{n} \mathrm{M}^{3} \mathrm{H}$-leucine was added. We also assumed that $10 \mathrm{nM}$ addition might reduce leucine intracellular isotope dilution by sup- pressing de novo synthesis of leucine. While $10 \mathrm{mM}$ addition yielded near maximum rates of leucine incorporation (Fig. 3a) it did not change bacterial growth rate (since leucine incorporation remained linear, Fig. 3b). Thus, $10 \mathrm{n} M$ addition maximized the participation of exogenous leucine in protein synthesis without increasing the overall rate of leucine incorporation into protein. This is supported by our observation that following addition of $7 \mathrm{n} M^{3} \mathrm{H}$-leucine the intracellular pool concentration remained essentially constant at $0.9 \mathrm{~m} M$. We point out that all amino acid pools were in the $m M$ range (Table 3 ).

Intracellular isotope dilution was found to be 2-fold by 2 independent methods. The first method compared the rate of exogenous ${ }^{3} \mathrm{H}$-leucine incorporation into protein with the rate of protein synthesis (measured as the increase of bacterial protein during the incubation of a $0.6 \mu \mathrm{m}$-filtrate; Exp. 3, Table 1). Exogenous leucine 


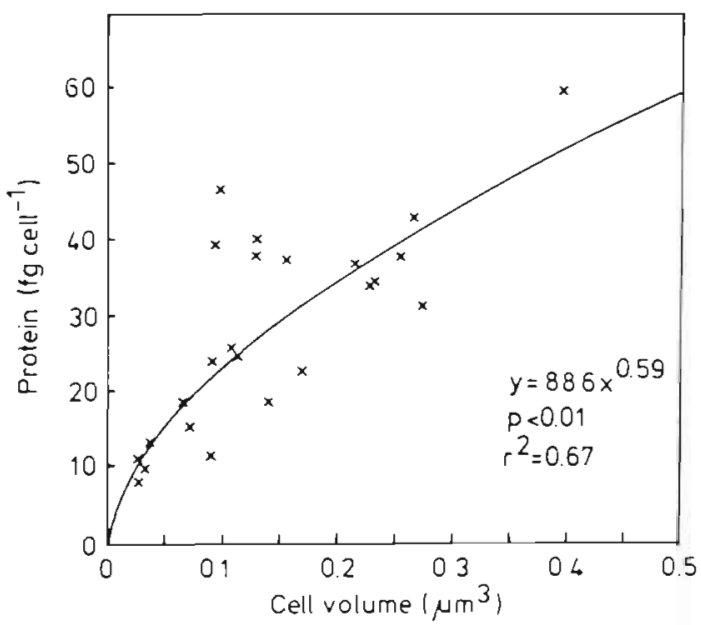

Fig. 2. Power functional relation between bacterial cell volume and cell protein of 25 samples of Exps. 1, 2 and 3, and additional samples $(0.4 \mu \mathrm{m}$ filtrates, 4 lowest values) from Scripps pier. Cell volumes cover the range between 0.026 and $0.395 \mu \mathrm{m}^{3}$ and protein that between 9.9 and $58.9 \mathrm{fg} \mathrm{cell}^{-1}$ All samples represent duplicate measurements

accounted for 35 to $97 \%$ (mean $=51 \pm 26 \%)$ of leucine needed to support the increase in bacterial protein (Table 1 ; the $28 \mathrm{~h}$ value which gave higher leucine incorporation than leucine production was excluded due to an underestimated growth rate). Thus, the extracellular isotope dilution was always $<3$-fold; the mean of all 5 determinations was 2-fold.

A second more direct method yielded a similar degree of intracellular isotope dilution. ${ }^{3} \mathrm{H}$-leucine was added to $0.6 \mu \mathrm{m}$ pre-filtered seawater yielding an extracellular leucine specific activity of $18.8 \mathrm{Ci} \mathrm{mmol}^{-1}$ (Fig. 4) During the incubation intracellular specific activity rose from 0 to $7.8 \mathrm{Ci} \mathrm{mmol}^{-1}(42 \%$ of the extracellular specific activity) within $10 \mathrm{~min}$ after adding ${ }^{3} \mathrm{H}$-leucine; it reached a maximum of $11.0 \mathrm{Ci} \mathrm{mmol}{ }^{-1}(61 \%$ of extracellular specific activity) within $30 \mathrm{~min}$.

\section{Bacterial production rates by BPP and TdR methods}

In a profile off Scripps pier the ratio of BPP:TdR varied between 0.49 and 1.55 (mean $=0.93$; Table 4 ) using our empirical relationship for BPP (see 'Discussion' for derivation of the factor). In profiles along an onshore-offshore transect of BPP and TdR it is evident that BPP and TdR covary closely with cell numbers and result in comparable production rates (Fig. 5). In the euphotic zone, ratios of BPP and TdR-based bacterial carbon production varied from 0.28 to 2.02 , but $70 \%$ of the values were between 0.5 and 2 . Only in 2 cases in aphotic waters gave this ratio values $>4$.

\section{DISCUSSION}

The discovery of an abundant bacterial flora in the marine pelagial (Zimmermann \& Meyer-Reil 1974, Hobbie et al. 1977) has been mainly noticed for its numerical import, yet it is equally significant in having shown that most pelagic bacteria are exceedingly small. We do not know the macromolecular composition, structure, and structure-function relationships of

Table 2. Mol \% of bacterial protein amino acids (BPAA) of samples of Exps. 2 and 3 and additional samples from Scipps pier (0.6 and $0.4 \mu \mathrm{m}$ filtrates, $n=47)$ and average amino acid mol \% of purified bacterial proteins $(n=69$, Reeck 1983). Since HPLC analysis did not include cysteine, lysine, proline, and tryptophane, the amino acid mol\% of the purified bacterial proteins were recalculated on the basis of the BPAA analysed. Means + standard error are given

\begin{tabular}{|c|c|c|c|c|}
\hline \multirow[t]{2}{*}{ Amino acid } & \multirow[t]{2}{*}{ BPAA (1) } & \multicolumn{2}{|c|}{ Purified bacterial proteins } & \multirow{2}{*}{$\frac{2}{1}$} \\
\hline & & Initial & Recalc. (2) & \\
\hline Aspartic acid & $15.5 \pm 3.82$ & $11.3 \pm 2.53$ & 13.3 & 0.85 \\
\hline Glutamic acid & $11.5 \pm 5.72$ & $10.5 \pm 2.59$ & 12.4 & 1.07 \\
\hline Serine & $10.2 \pm 6.25$ & $5.5 \pm 1.93$ & 6.4 & 0.63 \\
\hline Histidine & $2.8 \pm 2.28$ & $2.3 \pm 1.11$ & 2.7 & 0.94 \\
\hline Threonine + glycine & $14.6 \pm 4.49$ & $13.7 \pm 3.57$ & 16.1 & 1.10 \\
\hline Alanine + arginine & $12.8 \pm 5.53$ & $14.1 \pm 4.65$ & 16.6 & 1.30 \\
\hline Tyrosine & $5.1 \pm 2.61$ & $3.1 \pm 1.32$ & 3.6 & 0.69 \\
\hline Valine & $8.0 \pm 2.63$ & $7.4 \pm 1.64$ & 8.7 & 1.08 \\
\hline Phenylalanine & $5.3 \pm 1.90$ & $3.5 \pm 1.09$ & 4.1 & 0.77 \\
\hline Isoleucine & $6.6 \pm 2.49$ & $5.5 \pm 1.60$ & 6.4 & 0.98 \\
\hline Leucine & $7.3 \pm 1.91$ & $8.5 \pm 2.30$ & 9.9 & 1.35 \\
\hline Cysteine & - & $1.1 \pm 1.07$ & - & \\
\hline Lysine & - & $6.0 \pm 2.92$ & - & \\
\hline Methionine & - & $2.2 \pm 1.01$ & - & \\
\hline Proline & - & $4.3 \pm 1.26$ & - & \\
\hline Tryptophane & - & $3.1 \pm 1.32$ & - & \\
\hline
\end{tabular}


A

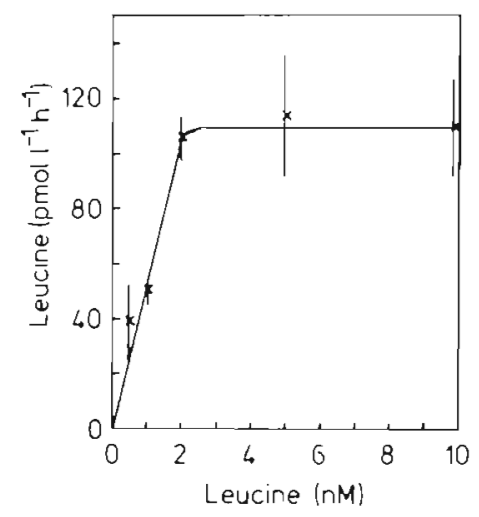

B

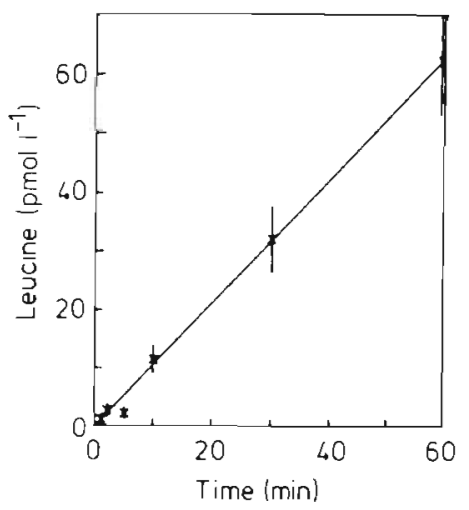

Fig. 3. (A) Concentration kinetic of ${ }^{3} \mathrm{H}$-leucine incorporation rates into the hot TCA precipitate of an unfiltered sample from Scripps pier (standard errors [SE] of triplicates are given). Incubations were $1 \mathrm{~h}$. (B) Time course of ${ }^{3} \mathrm{H}$-leucine incorporation rates into the hot TCA precipitate of an unfiltered sample from Scripps pier (SE of triplicates are given). ${ }^{3} \mathrm{H}$-leucine additions were $10 \mathrm{nM}$ (final concentration). Both incubations were within $4^{\circ} \mathrm{C}$ of ambient water temperature in the dark
Table 3. Amino acid pool concentrations of bacterial assemblages (0.6 $\mu \mathrm{m}$ filtrates) from Scripps pier. Samples $(n=17)$ are from the time course experiment in which the specific activity and isotope dilution of ${ }^{3} \mathrm{H}$-leucine in the bacterial pool was analyzed (Fig. 4)

\begin{tabular}{|lcc|}
\hline Amino acid & $\begin{array}{c}\text { Concentration } \\
(\mathrm{m} M)\end{array}$ & $\begin{array}{c}\% \text { of total } \\
\text { concentration }\end{array}$ \\
\hline Aspartic acid & $3.1 \pm 1.76$ & 4.1 \\
Glutamic acid & $36.2 \pm 17.60$ & 46.8 \\
Asparagine & $15.7 \pm 8.36$ & 20.8 \\
Serine & $2.1 \pm 1.37$ & 2.8 \\
Glutamine & $3.0 \pm 3.53$ & 3.9 \\
Histidine & $1.5 \pm 0.59$ & 2.0 \\
Threonine + glycine & $3.8 \pm 1.14$ & 5.0 \\
b-Alanine & $1.3 \pm 0.32$ & 1.7 \\
Alanine + arginine & $4.8 \pm 1.35$ & 6.4 \\
Tyrosine & $1.0 \pm 0.44$ & 1.3 \\
Methionine & $0.6 \pm 0.21$ & 0.8 \\
Valine & $0.8 \pm 0.20$ & 1.1 \\
Phenylalanine & $0.5 \pm 0.27$ & 0.7 \\
Isoleucine & $0.3 \pm 0.15$ & 0.5 \\
Leucine & $0.9 \pm 0.24$ & 1.1 \\
\hline
\end{tabular}

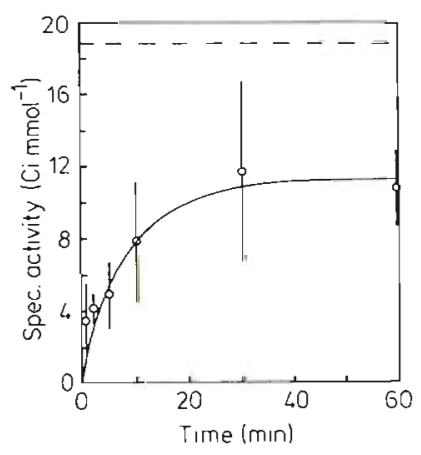

Fig. 4. Time course of ${ }^{3} \mathrm{H}$-leucine specific activity in the intracellular pool of a $0.6 \mu \mathrm{m}$ filtrate from Scripps pier. Standard errors of triplicates are given. Dashed line shows specific activity of ${ }^{3} \mathrm{H}$-leucine after addition to sample. For details see text these small bacteria; our perceptions of the macromolecular composition of pelagic bacteria are based on extrapolations from cultured bacteria which are 10 to 100 times more voluminous. It is interesting, therefore, to elucidate the adaptive biochemical strategies specific to the diminutive bacteria as they occur in the marine pelagial.

\section{Protein content and macromolecular composition of pelagic bacteria}

The power-function relationship between cell volume and protein (Fig. 2) shows that as the cells become small the protein:cell volume ratio increases greatly (Table 5). Our smallest bacteria $\left(0.026 \mu \mathrm{m}^{3}\right)$ had $465 \mathrm{mg}$ protein $\mathrm{ml}{ }^{1}$ cell volume while this value decreased to $152 \mathrm{mg} \mathrm{ml}^{-1}$ cell volume in $0.4 \mu^{3} \mathrm{~m}^{3}$ bacteria, similar to that reported for Escherichia coli cultures (Ingraham et al. 1983). Clearly, there is a large and progressive increase in protein 'concentration' as bacteria become smaller. The very high protein concentration in the diminutive bacteria imposes space constraints on accomodating other macromolecular components as well as cellular water. Table 5 shows a rough macromolecular inventory to estimate the cell dry weight and cell-carbon. Protein and DNA were based on measurements of bacterial assemblages; other components were extrapolated from cultures but we took into account the effect of cell size on the proportion of cell wall and cell membrane. Taken at face value our calculation suggests that as bacteria become very small their dry weight becomes rich in DNA (13\% of dry weight in $0.026 \mu \mathrm{m}^{3}$ bacteria compared with $5 \%$ in $0.4 \mu \mathrm{m}^{3}$ cells and $3 \%$ in E. coll [Ingraham et al. 1983]) and protein and poor in RNA. The low RNA values (even lower than DNA) may seem surprising but are reasonable for bacteria with doubling times on the order of $>1 \mathrm{~d}$ because bacterial RNA concentration is a function of 
Table 4. Bacterial protein production (BPP) and thymidine-based bacterial secondary production (TdR) in a depth profile off Scripps pier For conversion of BPP, $3595 \mathrm{~g}$ protein (mol leucine) $)^{-1}$ (2-fold isotope dilution) was used. For conversion of TdR, $1.70 \times 10^{18}$ cells (mol thymidine) $)^{-1}$ and $19 \mathrm{fg} \mathrm{C}$ cell $^{-1}$ (Table 5) were used. Rates are $\mathrm{l}^{-1} \mathrm{~h}^{-1}$

\begin{tabular}{|c|c|c|c|c|c|}
\hline \multirow{2}{*}{$\begin{array}{l}\text { Depth } \\
\text { (m) }\end{array}$} & \multirow{2}{*}{$\begin{array}{c}\text { BPP } \\
\text { protein (ng) }\end{array}$} & \multicolumn{2}{|c|}{$T d R$} & \multirow{2}{*}{$\frac{\mathrm{BPP}}{\mathrm{TdR}}$} & \multirow{2}{*}{$\begin{array}{c}\text { Protein } \\
\text { New cell } \\
\text { (fg cell }^{-1}\end{array}$} \\
\hline & & $10^{6}$ cells & Carbon (ng) & & \\
\hline 0 & 204 & 10.0 & 190 & 1.07 & 20.4 \\
\hline 15 & 243 & 26.4 & 501 & 0.49 & 9.2 \\
\hline 30 & 287 & 22.1 & 419 & 0.68 & 8.0 \\
\hline 50 & 351 & 11.9 & 226 & 1.55 & 29.5 \\
\hline Pier & 217 & 13.6 & 258 & 0.84 & 16.0 \\
\hline
\end{tabular}

growth rate (Kerkhof \& Ward 1987). Our attempts to directly measure RNA in pelagic bacteria failed but indicated that RNA was either $<1 \mathrm{fg}^{\text {cell }}{ }^{-1}$ or was degraded during sample preparation (Pontius-Brewer \& Azam unpubl.).

Perhaps the most striking observation is that the diminutive bacteria are very ' $\mathrm{dry}$ '; $0.026 \mu \mathrm{m}^{3}$ bacteria had only $46 \%(\mathrm{v} / \mathrm{v})$ water while $0.4 \mu^{3}$ bacteria had $82 \%$, a percentage comparable to cultured Escherichia coli. This phenomenon raises the question whether the water content in pelagic bacteria has significant physiological implications for their survival strategies
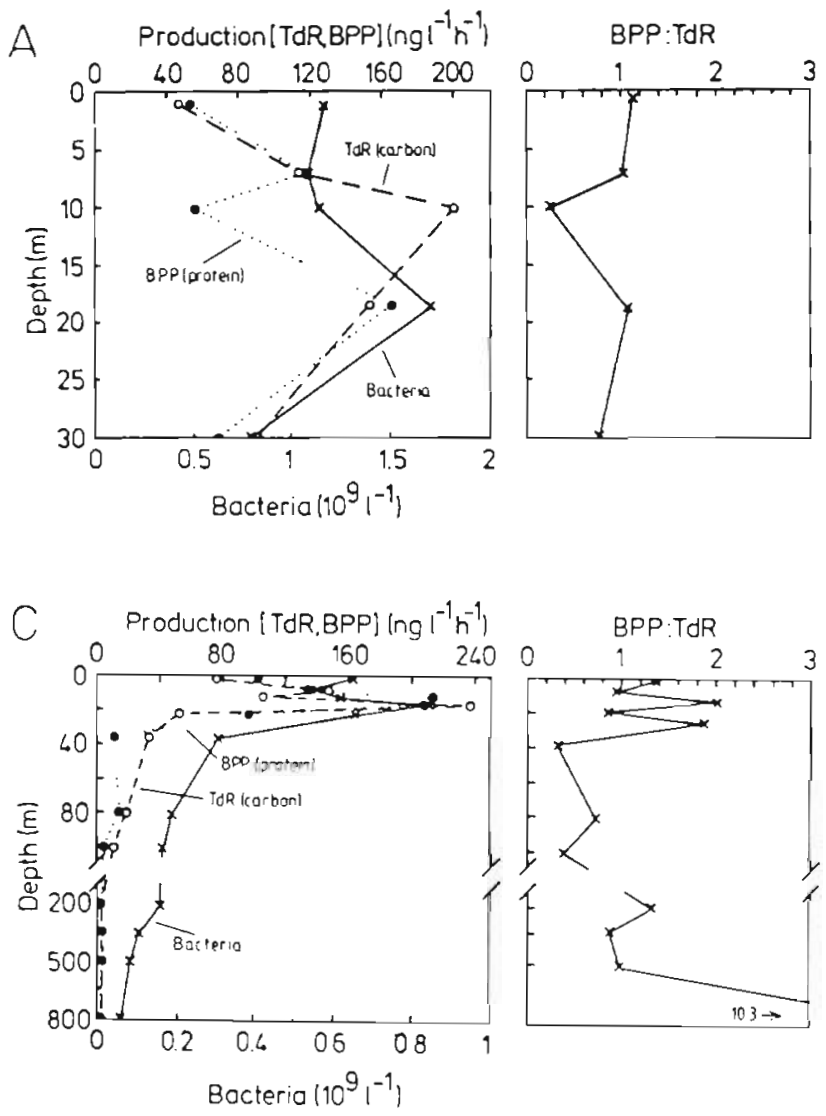

in the sea. Our observations hypothesize a mechanism whereby diminutive bacteria change their cell size by a disproportionately varying water content as compared to biomass, thus reducing the energetic costs.

Interestingly, the protein:dry weight ratio remained essentially constant $(63 \pm 1 \%)$ throughout the range of cell sizes considered (Table 5). This value is within the range reported for large cultured bacteria (50 to $70 \%$; Herbert 1976). Table 5 also shows that cell carbon is an essentially constant fraction ( $54 \pm 1 \%$ ) of dry weight and has a constant relationship with cell protein.

The constancy of protein:dry weight and carbon:dry
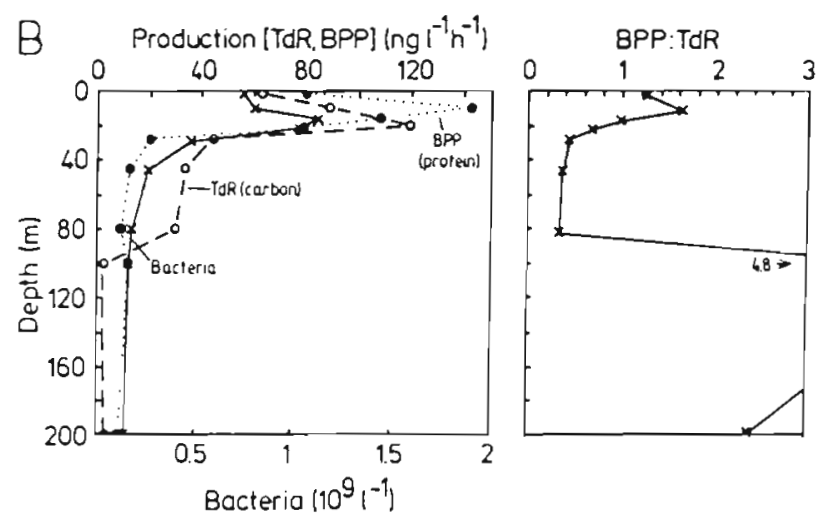

Fig. 5. Bacterial cell numbers, protein production (BPP), thymidine-based carbon production (TdR), and BPP: TdR ratio at 3 stations on an onshore-offshore transect in the Southern California Bight. Stations are: (A) $33^{\circ} 53.9^{\prime} \mathrm{N}, 118^{\circ} 28.3^{\prime} \mathrm{W}_{\text {; }}$ (B) $33^{\circ} 50.4^{\prime} \mathrm{N}, 118^{\circ} 36.2^{\prime} \mathrm{W} ;$ (C) $33^{\circ} 45.5^{\prime} \mathrm{N}, 118^{\circ} 47.6^{\prime} \mathrm{W}$ Note different scales at each station 
periplasmic gel becomes thicker in small planktonic bacteria.

A consequence of the increasing dry weight: water ratio with decreasing cell volume is that the cell density increases (Table 6). This is because protein and DNA have substantially higher densities than water and constitute a major fraction of dry weight. Bratbak \& Dundas (1984) and Bjørnsen (1986) also found evidence and argued that small pelagic bacteria have higher densities and lower water contents than previously anticipated. We note that because of the volume dependence of the cell water content the refractive index of pelagic bacteria should vary with cell size. The possible bio-optical implications of this phenomenon merit examination

It is interesting to note that the diminutive cells maintain intracellular amino acid pool concentrations in the $m M$ range (Table 3 ) as in cultured bacteria (Holden 1962). Marine pelagic bacteria achieve this against a concentration gradient on the order of $10^{6}$ ! Highly efficient uphill transport systems are thus indicated. We further note that glutamic acid and asparagine dominate the amino acid pool. Glutamic acid is the primary ammoniation site and a route for input of alpha-ketoglutaric acid into the tricarboxylic acid cycle (Brown 1980); hence its high pool concentration is not surprising.

Our results are consistent with, and explain, recent findings of very high C:cell volume ratios determined from carbon measurements in bacterial cultures or in size-fractionated natural bacterial assemblages: $354 \mathrm{mg} \mathrm{C} \mathrm{ml}^{-1}$ (Bjørnsen 1986), $380 \mathrm{mg} \mathrm{C} \mathrm{ml}^{-1}$ (Lee \& Fuhrman 1987), and $560 \mathrm{mg} \mathrm{C} \mathrm{ml}^{-1}$ (Bratbak 1985). Lee \& Fuhrman also found that 0.036 to $0.073 \mu \mathrm{m}^{3}$ cells uniformly contained $20 \mathrm{fg} \mathrm{C} \mathrm{Cell}^{-1}$. Our calculated carbon values for cells in this volume range are somewhat lower (13 to $19 \mathrm{fg}$, Table 5) and size-dependent. The C:cell volume ratios we calculated are only as high as those found recently in the smallest cells and decrease with increasing cell volume to a value as determined by Watson et al. (1977) and known from Escherichia coli (Ingraham et al. 1983). Our results support the general conclusion that the carbon of diminutive pelagic bacteria is a much more important fraction of aquatic biomass carbon and particulate organic carbon (Fuhrman et al. 1987, Simon \& Tilzer 1987, Cho \& Azam 1988) than previously believed.

\section{Leucine incorporation as a measure of BPP}

Our results indicate that BPP can be reliably measured in pelagic samples on the basis of ${ }^{3} \mathrm{H}$-leucine incorporation. Although we used leucine, the method can also be calibrated for use with other amino acids since all parameters needed can be derived in the same way as for leucine. The use of amino acids with a rather constant mol\% of bacterial protein is preferable because conversion of incorporation rates into BPP of such amino acids is most reliable.

Leucine incorporation is virtually specific for bacteria provided low ( $\mathrm{n} M$ ) concentrations are used (Kirchman et al. 1985). We used $10 \mathrm{nM}{ }^{3} \mathrm{H}$-leucine to maximize the extracellular specific activity by overwhelming the ambient leucine pool, as well as to increase leucine uptake and thereby the participation of exogenous ${ }^{3} \mathrm{H}$ leucine in protein synthesis. Addition of $10 \mathrm{nM}$ did not change protein synthesis rate; the time-course of leucine incorporation into protein was linear for at least $1 \mathrm{~h}$ (Fig. 3b). Thus, while $10 \mathrm{nM}$ addition generally represented a 10 -fold increase in the ambient leucine concentration it neither stimulated nor inhibited protein synthesis.

The BPP method is highly sensitive for measuring bacterial production because protein is a major dry weight component. The BPP method is an order of magnitude more sensitive than the $T d R$ method. While both ${ }^{3} \mathrm{H}$-leucine and ${ }^{3} \mathrm{H}$-thymidine are commercially available at high specific activities (TdR: 50 to $100 \mathrm{Ci}$ $\mathrm{mmol}^{-1}$; leucine: 100 to $200 \mathrm{Ci} \mathrm{mmol}{ }^{-1}$ ), the biosynthesis of a $0.05 \mu^{3}$ bacterium requires the incorporation of about 10 times greater ${ }^{3} \mathrm{H}$ of leucine into protein than ${ }^{3} \mathrm{H}$ of TdR into DNA $\left(10^{17}\right.$ and $10^{18} \mathrm{~mol}$, or ca 1 and $0.1 \mathrm{cpm}$, respectively). The BPP method is, therefore, particularly suitable for low bacterial production environments such as mesopelagic and bathypelagic depths, where the TdR method is stretched to its limit. The high BPP/TdR ratios in a few of our samples in the mesopelagic zone with very low TdR-based production rates (Fig. 5) indicate this.

An attractive feature of the BPP method is that the intracellular pool specific activity of ${ }^{3} \mathrm{H}$-leucine can be measured by HPLC (but see below). The measurement of the pool-specific activity allows conversion of ${ }^{3} \mathrm{H}$ leucine incorporation into the protein fraction directly into BPP. Sample processing for pool-specific activity measurements is logistically simple, and can be done in the field on a large number of samples (see 'Material and Methods'). After pool extraction the samples may be frozen for later analysis since any partial degradation of amino acids should not change the specific activity. Pool turnover, at least for leucine, is slow (20 min). thus the specific activity should not decrease significantly during fractionation and pool extraction.

In our experiments leucine intracellular isotope dilution was 2-fold at $10 \mathrm{n} M$ added leucine. Two different approaches yielded roughly the same degree of isotope dilution. Since the degree of isotope dilution may vary spatially and temporally due to changing environmental conditions we suggest directly measuring the pool specific activity in representative samples. If minimum estimates of BPP will do, then one might 
forego the measurement of isotope dilution. We hesitate to suggest using a 'standard' isotope dilution of 2 fold because we do not know what controls isotope dilution. However, BPP measurements in the subarctic Pacific also revealed a 2 -fold isotope dilution of leucine added at $10 \mathrm{n} M$ final concentration (Simon \& Kirchman 1988). It took 10 to $30 \mathrm{~min}$ to reach the intracellular specific activity plateau. Short (few min) incubations will therefore underestimate BPP if the specific activity is measured only at the end of the incubation. One hour incubation would be adequate.

Measuring the precursor pool specific activity is by no means a panacea. Mixed natural assemblages of different bacterial subpopulations could conceivably achieve very different ${ }^{3} \mathrm{H}$-leucine specific activities. In an extreme situation, a large fraction of the bacterial assemblage may be non-responsive, neither synthesizing protein nor taking up ${ }^{3} \mathrm{H}$-leucine, and only a small fraction may actively take up and incorporate ${ }^{3} \mathrm{H}$ leucine, but both fractions maintain a normal endogenous leucine pool. During pool extraction the nonresponsive cells will lower the specific activity estimate of the total assemblage, thus causing an overestimation or protein synthesis calculated on the basis of ${ }^{3} \mathrm{H}$ leucine incorporation and the assemblage-average ${ }^{3} \mathrm{H}$ leucine specific activity. Imperfect size-fractionation could also lower ${ }^{3} \mathrm{H}$-leucine specific activity by introducing small phytoplankton cells, containing unlabelled leucine pools, into the bacterial fraction. Our pool-specific activity measurements by 2 independent

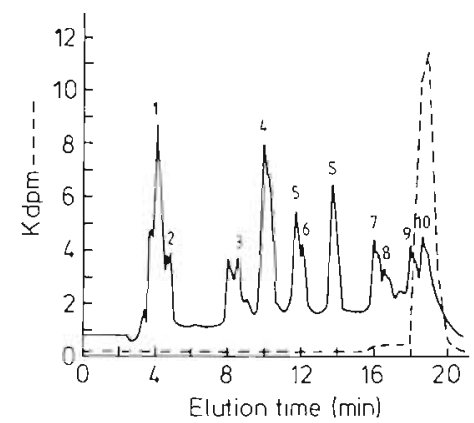

Fig. 6. HPLC chromatogram of a bacterial protein amino acid sample of Exp.3 after $2 \mathrm{~h}$ incubation with ${ }^{3} \mathrm{H}$-leucine and hydrolysis to amino acids. 1: asp, 2: glu, 3: ser, $4:$ gly + thr, 5 : ala + arg, 6: tyr, 7: val, 8: phe, 9: ile, 10: leu, S: alpha-amino butyric acid as internal standard $(10 \mathrm{nM})$. Dashed line: ${ }^{3} \mathrm{H}-$ radioactivity of the recollected fractions (1 min) of the eluate after analysis

methods showed only 2 -fold isotope dilution. Therefore, our samples could not have included large nonresponsive populations. However, if one finds a high degree of isotope dilution one would require independent verification (e.g. by autoradiography) that the isotope dilution is not due to the presence of non- or minimally responsive organisms. In any case, the true rate or protein synthesis can be reliably bracketed by calculating the minimum rate (assuming no isotope dilution) and maximum rate (based on the measured precursor pool-specific activity)

A possible source of error in the BPP method is that some ${ }^{3} \mathrm{H}$-leucine may have been metabolized to other amino acids which would then become incorporated into protein. Fig. 6 shows that this is not a problem. Hydrolysis of bacterial protein after ${ }^{3} \mathrm{H}$-leucine incorporation yielded negligible ${ }^{3} \mathrm{H}$ in any amino acid other than leucine. Only a few experiments showed slight incorporation of ${ }^{3} \mathrm{H}$ into alanine (data not shown). Kirchman et al. (1985) also found no leucine metabolism by an independent method.

\section{Calculation of bacterial protein production from leucine incorporation}

BPP is calculated from ${ }^{3} \mathrm{H}$-leucine incorporation by the following equation:

$\operatorname{BPP}(\mathrm{g})=\left(\mathrm{mol}\right.$ leucine $\left._{\mathrm{inc}}\right) \times(100 / 7.3) \times 131.2 \times \mathrm{ID}$

$$
=\left(\mathrm{mol} \text { leucine } e_{\text {ind }}\right) \times 1797 \times \mathrm{ID}
$$

where mol leucine inc $=$ moles of exogenous leucine incorporated $100 / 7.3=100 / \mathrm{mol} \%$ of leucine in protein; 131.2 = formula weight of leucine; ID $=$ intracellular isotope dilution of ${ }^{3} \mathrm{H}$-leucine. If isotope dilution is not known, the theoretical minimum estimate of BPP can be made by assuming no isotope dilution (i.e. all protein leucine being derived exogenously). Using 2 -fold isotope dilution, as in our samples,

$$
\operatorname{BPP}(g)=\left(\text { mol leucine } e_{\text {ind }}\right) \times 1797 \times 2
$$

Or, we can directly calculate BPP from intracellular pool specific activity (SA) as:

$$
\operatorname{BPP}(\mathrm{g})=\left(\mathrm{dpm}_{1 \mathrm{nc}}\right) \times \mathrm{SA}^{-1} \times 131.2
$$

As stated above,BPP can be converted into bačterial carbon production by multiplying it by 0.86 . If protein cell $^{-1}$ is known (from cell volume and the correlation in Fig. 2 ; but consider an $18 \%$ increase - see Table 5) then BPP can also be converted into bacterial cell multiplication rate.

Empirical calibration of the method in dilution cultures may be adequate in some environments (ChinLeo \& Kirchman 1988) and when measurements of the pool-specific activity cannot be performed.

\section{Experimental procedure}

Our 'standard' procedure is this: Place 5 to $10 \mathrm{ml}$ seawater into clean test tubes. Add $10 \mathrm{n} M{ }^{3} \mathrm{H}$-leucine (final concentration). Incubate $1 \mathrm{~h}$. Extract the cells in 
boiling 5\% TCA for $30 \mathrm{~min}$, cool down, fjlter, rinse, and radioassay the sample. Convert mol ${ }^{3} \mathrm{H}$-leucine incorporated to BPP either by assuming no isotope dilution (theoretical minimum estimate) or by measuring the pool-specific activity as follows: Add $10 \mathrm{nM}$ ${ }^{3} \mathrm{H}$-leucine to a separate sample with a total of about $10^{8}$ cells. Incubate for $1 \mathrm{~h}$ and quickly filter the sample through a $0.6 \mu \mathrm{m}$ Nuclepore filter onto a $0.2 \mu \mathrm{m}$, $47 \mathrm{~mm}$ Nuclepore filter. Extract in $3 \mathrm{ml}$ of boiling water for 3 to $4 \mathrm{~min}$. Chill the sample and keep it on ice or frozen (for longer storage) until analysis by HPLC.

\section{Field comparisons oí BPP and TdR methods}

Bacterial production rates based on protein and DNA synthesis were in fair agreement in field samples examined by us (Table 4, Fig. 5). The BPP measurements thus provide an independent confirmation of the significant participation of bacteria in consuming primary production and as a fundamental component of the microbial loop. Table 4 also illustrates that the use of both BPP and TdR methods allows determination of protein synthesis per new cell. This parameter may indicate whether smaller or larger than average size bacteria were responsible for the growth and whether DNA and protein synthesis are coupled or uncoupled during different growth stages. The BPP:TdR ratios in Fig. 5 also reflect various growth stages which are to be expected in a heterogenous environment such as the water column. Our preliminary field work, however, was not designed to address the environmental factors which may influence this parameter. It would provide useful insights into the growth responses of bacteria to changing nutrient and physico-chemical conditions in the bacterium's environment.

\section{CONCLUSION}

We have shown the usefulness of measuring bacterial protein content and protein synthesis rates for quantifying the role of bacteria in carbon fluxes in aquatic ecosystems. Bacterial protein synthesis is an attractive approach because it can directly estimate bacterial carbon production, a parameter of central importance in ecological and biogeochemical studies. It should complement other approaches, such as thymidine incorporation, for measuring bacterial growth in aquatic environments. Further, our observations on the macromolecular composition of the diminutive bacteria raise questions for future studies on the biochemical adaptation of pelagic bacteria to their dynamic natural environment.
Acknowledgements. This work was supported by DOE grant \# DE-FG05-85-ER60336. M.S. was supported by a fellowship from the Deutsche Forschungsgemeinschaft.

\section{LITERATURE CITED}

Ammerman, J. W., Fuhrman, J. A., Hagström, A., Azam, F. (1984). Bacterioplankton growth in seawater: I. Growth kinetics and cellular characteristics in seawater-cultures. Mar. Ecol. Prog. Ser 18: 31-39

Azam, F., Fenchel, T., Field, J. G., Gray, J. S., Meyer-Reil, L.A., Thingstad, F. (1983). The ecological role of watercolumn microbes in the sea. Mar. Ecol. Prog. Ser. 10: $257-263$

Bjornsen, P. K. (1986). Automatic determination of bacterioplankton biomass by image analysis. Appl. environ. Microbiol. 51 1199-1204

Bratbak, G. (1985). Bacterial biovolume and biomass estimations. Appl. environ. Microbiol. 49: 1488-1493

Bratbak, G., Dundas, I. (1984). Bacterial dry matter and biomass estimations. Appl. environ. Microbiol. 48: 755-757

Brown, C. M. (1980). Ammonia assimilation and utilization in bacteria and fungi. In: Payne, J. W. (ed.) Microorganisms and nitrogen sources. Wiley, New York, p. 511-535

Chin-Leo, G., Kirchman, D. L. (1988). Estimation of bacterial production in marine waters from the simultaneous incorporation of thymidine and leucine. Appl. environ. Microbiol. 54: 1934-1939

Cho, B. C., Azam, F. (1988). Major role of bacteria in biogeochemical fluxes in the ocean's interior. Nature, Lond. 332: 441-443

Cole, J. J., Findlay, S., Pace, M. L. (1988). Bacterial production in fresh and salt-water ecosystems: a cross-system overview. Mar. Ecol. Prog. Ser. 43: 1-10

Cuhel, R. L., Taylor, C. D., Jannasch, H. W. (1982). Assimilatory sulfur metabolism in marine microorganisms: considerations for the application of sulfate incorporation into protein as a measure of natural population protein synthesis. Appl. environ. Microbiol. 43: 160-168

Fuhrman, J. A., Azam, F. (1980). Bacterioplankton secondary production estimates for coastal waters of British Columbia, Antarctica, and California. Appl. environ. Microbiol. 39: 1085-1095

Fuhrman, J. A., Azam, F. (1982). Thymidine incorporation as a measure of heterotrophic bacterioplankton production in marine surface waters: evaluation and field results. Mar Biol. 66: 109-120

Fuhrman, J. A., Bell, T M. (1985). Biological considerations in the measurements of dissolved free amino acids in seawater and implications for chemical and microbiological studies. Mar Ecol. Prog. Ser. 25: 13-21

Fuhrman, J. A., Sleeter, T., Carlson, C. (1987). Oligotrophic ocean biomass is dominated by non-photosynthetic bacteria, even in the euphotic zone. EOS 68: 1729

Herbert, D. (1976). Stoichiometric aspects of microbial growth In: Denn, A. C. R., Ellwood, D. C., Evans, C. G. T., Melling, J. (eds.) Continuous culture 6: Applications and new fields Ellis Horwood, Chichester, p. 1-30

Herbert, D., Phipps, P. J., Strange, R. E. (1971). Chemical analysis of microbial cells. In: Norris, J. R., Ribbons, D. W (eds.) Methods in microbiology, Vol. 5B. Academic Press, New York, p. 210-244

Hobbie, J. E., Daley, R. J., Jasper, S. (1977). Use of nuclepore filters for counting bacteria by fluorescence microscopy. Appl. environ. Microbiol. 33: 1225-1228 
Hobot, J. A., Carlemalm, E., Villiger, W., Kellenberger, E. (1984). Periplasmic gel: new concept resulting from reinvestigation of bacterial cell envelope ultrastructure by new methods. J. Bacteriol. 160: 143-152

Holden, J. T (1962). The composition of microbial amino acid pools. In: Holden, J. T. (ed.) Amino acid pools, distribution, formation, and function of free amino acids. Elsevier, Amsterdam, p. 73-108

Ingraham, J. L., Maloe, O., Neidhardt, F. C. (1983). Growth of the bacterial cell. Sinauer Association, Sunderland, Mass.

Kerkhof, L., Ward, B. B. (1987). Relationship between ribosomal content and growth rate in a marine bacterium. EOS 68: 1677

Kirchman, D. L., K'Nees, E., Hodson, R. (1985). Leucine incorporation and its potential as a measure of protein synthesis by bacteria in natural aquatic systems. Appl. environ. Microbiol. 49: 599-607

Kirchman, D. L., Newell, S. Y., Hodson, R. E. (1986). Incorporation versus biosynthesis of leucine: implications for measuring rates of protein synthesis and biomass production by bacteria in marine systems. Mar. Ecol. Prog. Ser. 32: 47-59

Lee, S., Fuhrman, J. A. (1987). Relationship between biovolume and biomass of naturally derived marine bacterioplankton. Appl, environ. Microbiol. 53: 1298-1303

Lindroth, P., Mopper, K. (1979). High performance liquid chromatographic determinations of subpicomole amounts of amino acids by precolumn fluorescence derivatization with o-phthaldialdehyde. Analyt. Chem. 51: 1667-1674
Moriarty, D. J. W (1986). Measurement of bacterial growth rates in aquatic systems from rates of nucleic acid synthesis. Adv. microb. Ecol. 9: 245-292

Reeck, G. R. (1983). Amino acid composition of selected proteins. In: Laskin, A. I., Lechevalier, H. A. (eds.) Handbook of microbiology, Vol. 2: Microbial composition. CRC Press, Boca Raton, p. $15-25$

Riemann, B., Sondergaard, M. (1986). Carbon dynamics in eutrophic, temperate lakes. Elsevier, Amsterdam

Simon, M. (1987). Biomass and production of small and large free-living and attached bacteria in Lake Constance. Limnol. Oceanogr. 32: 591-607

Simon, M. Kirchman, D. L. (1988). Isotope dilution during bacterial amino acid uptake in the subartic Pacific: evidence for ammonium utilization by bacteria. EOS 69: 1146

Simon, M., Tilzer, M. M. (1987). Bacterial response to seasonal changes in primary production and phytoplankton biomass in Lake Constance. J. Plankton Res. 9: 535-552

Stanier, R. Y., Ingraham, J. L., Wheelis, M. L., Painter, P. R. (1986). The microbial world. Prentice Hall, Englewood, New Jersey

Watson, S. W., Novitsky, T J., Quinby, H. L., Valois, F. W. (1977). Determination of bacterial number and biomass in the marine environment. Appl. environ. Microbiol. 33: $940-945$

Zimmermann, R., Meyer-Reil, L.-A. (1974). A new method for fluorescence staining of bacterial populations on membrane filters. Kieler Meeresforsch. 30: 24-26 


\section{Erratum}

Re: Simon \& Azam, Mar. Ecol. Prog. Ser. 51: 201-213, 1989

- p. 201, Abstract

Line 8: replace '... mean diameters from 0.026 to $0.4 \mu \mathrm{m}$.' by '... mean volumes from 0.026 to $0.4 \mu^{3}$.'

Line 10: replace '... $0.026 \mu \mathrm{m}$ bacteria.'

$$
\text { by ' } .0 .026 \mu \mathrm{m}^{3} \text { bacteria.' }
$$

- p. 212, Acknowledgements

Replace first sentence by 'This work was supported by NSF grant \# OCE 85-01363 and DOE grant \# DE-FG05-85-ER60336.' 